\title{
ENTREPRENEURSHIP AND WORK INNOVATION AMONG NURSE MANAGERS AT PORT SAID GOVERNMENTAL HOSPITALS
}

\section{Samea Mohsen Mahmoud Wardan'; Sanaa Abdel Azim Ibrahim ²; Ghada Mosaad Mohamed Elghabbour ${ }^{3}$}

Head Nurse at Ezbet Al-Burj central Hospital, Damietta Governorate ${ }^{1}$; Prof. of Nursing Administration, Faculty of Nursing, Port Said University 2; Lecturer of Nursing Administration, Faculty of Nursing, Port Said University ${ }^{3}$

\begin{abstract}
Background: Entrepreneurship and innovation are widely regarded as an important basis for competitive advantage in work environment and enhancing capabilities for work growth and the wealth of nations. Aim: This study aimed to examine the relation between entrepreneurship and work innovation among nurse managers at Port Said governmental hospitals. Subjects and Method: A descriptive correlational research design was utilized for the present study. Setting: This study was carried out at Port Said seven governmental hospitals namely: Port-Said general hospital, El-Zohour general hospital, El-Nasr hospital, Ophthalmology hospital, fever hospital, Chest Disease hospital and Obstetrics and Gynecology Specialist hospital, all hospital affiliated to Ministry of Health. Subject: This study was included (101) nurse managers. Tools of data collection: Two tools were utilized namely: The characteristics of entrepreneurship questionnaire and work innovation questionnaire. Results: The study revealed that the majority of nurses' managers haven't entrepreneurial characteristics and the majority of nurses' managers haven't work innovation. Conclusion: There was statistically significant positive correlation between nurse managers' characteristics of entrepreneurship and the work innovation. Recommendations: Improve self-confidence by further engagement and encourage their ability to achieve. Attend conferences, workshops and training program about entrepreneurship characteristics and work innovation to create an entrepreneurial character and enhance innovative behavior.
\end{abstract}

Key Words: Entrepreneurship, Nurse Manager, Work Innovation. 


\section{INTRODUCTION}

The health field being aware of the significance of patient care; the role of nurses is more prominent (Zhou, 2018). Moreover, concerning the professional and advanced nursing improvement and advances in new care models, the nurses are expected to develop their roles at different care levels from the health systems of the society and primary care to acute, protective and long-time care which is impossible without provoking them to be innovative and have entrepreneurship (Wilson, Whitaker \& Whitford, 2012).

İrmiş and Özdemir, (2011) defined entrepreneurship as recognizing work opportunities and exhibiting the most effective risk management preparation whilst creating value by applying managerial skills. In addition, entrepreneurship is described as an activity to identify an opportunity, to initiate an action to utilize it, and to create a work to implement the actions purposely to make benefits (Peverelli \& Song, 2012). Also, Entrepreneurship is defined as the institutionalization or the development of something in order to provide benefits to the individuals and society (Andrade, 2015).

According to Singer, Amoros \& Arreola (2015), the importance of entrepreneurship that helping to achieve health development, competitiveness, job creation and national prosperity has led to a marked global interest into the development of work, in the hope that will lead to an increase in social, health and organizational development. Additionally management through nurse entrepreneurship increases autonomy in practice, advances professionalism and will transform the healthcare delivery system (Smith, 2015).

An entrepreneur is someone who organizes, manages and assumes the risk of a work (Merriam-Webster, 2016), and an originator or creator of a benefit to organization (Ogundele \& Abiola, 2012). Successful entrepreneurs have a personality trait that displays the psychological characteristics of internal locus of control, high self-esteem, propensity to take risks, tolerance of ambiguity, need for achievement and innovativeness (Koe, Sa'ari \& Majid, 2012).

Entrepreneurship and innovation are widely regarded as an important basis for competitive advantage in a rapidly changing work environment, enhancing capabilities for sustainable work growth and the wealth of nations (O'Connor, 2013). ). Besides, the combination of innovation and entrepreneurship with plan increases the organization's success and value (Hisrich, 2014). 
Additionally, in order to keep up with the rapidly developing knowledge and scientific era and to manage global competition well, innovation in nursing has become compulsory (Kartal, 2018). So, many hospitals have actively encouraged nurses to participate in innovation to improve the quality of nursing care (Weng, Huang \& Lin, 2013).

The American Nurses Association (2017), defines innovation as setting new thoughts into practice or existing ideas into the practice of new methods. Besides, an innovative nurse manager is competitive, constantly seeking, constantly introducing changes and improvements, (Nawrat, 2013). Also, innovative work behavior refers to the revision or to the implementation of new practices and processes to improve the quality of services and meet the ever-increasing challenges facing the organization (Bagheri \& Akbari, 2018).

Nurse managers have a responsibility to induce changes in the clinical environment and this responsibility of nurse managers has become more important than ever due to demands for rationalization, cost cuttings, and reduced lengths of hospital stay (Japanese Nursing Association, 2016). Moreover, Moloi and Nkhahle-Rapita (2014), asserted that entrepreneur's managers are individuals who accept risks and who are innovative in terms of their work management skills.

Therefore, nurse manager plays fundamental roles in facilitating new idea creation and implementation by nurses as well as creating the supportive environment that fosters innovation processes in the organization (Chen, 2014). As well as, innovation has become an important factor in handling competitive advantage and modernization (TLS, 2019).

Several previous studies suggested that dimension of innovative work behavior consists of opportunity exploration, idea generation, idea promotion and idea realization (Kaur \& Gupta, 2016). In addition, Opportunity exploration which contributes to the idea generation which defined as a dynamic process of creation and association, generation of representations and categories of opportunities, and communication of ideas which can be in the form of abstract, concrete, or visual (Kheng, Mahmoud, 2013).

Idea promotion involves the introduction and dissemination of these ideas in the work environment by convincing key actors or key persons and assembling supporters for the innovation process (Messmann, 2017). Moreover, idea promotion which is aimed at gaining the group's approval and necessary resources for idea realization or also known as the stage of implementation. At the point when the organization have decided to develop, test and commercialize, idea realization or the implementation is taking place (Jong \& Hartog, 2010) 
and innovation is thus becoming part of the organization working process (Kheng\& Mahmoud, 2013).

\section{Significance of the study}

The nurses need to develop their working by having entrepreneurial and innovative characteristics at different care levels to respond to the growing and emerging needs in the health sector (Jahani, Abedi, Khoshknab \& Elahi, 2018). So, entrepreneurship is basis to the survival of organizations through constant innovation that translates into the development of new services (Marques \& Ferreira, 2019). From this point of view, both the entrepreneurship and work innovation are very important subjects for any organizations to reach desired objectives and quality of human and work life. Therefore, this study aims to examine the relation of entrepreneurship and work innovation among nurse managers at Port Said governmental hospitals.

\section{AIM OF STUDY}

The present study aims to examine the relation between entrepreneurship and work innovation among nurse managers at Port Said governmental hospitals.

\section{Research Question:}

1. Are nurse managers having the characteristics of entrepreneurship at Port Said governmental hospitals?

2. What are nurse managers 'abilities for work innovation?

3. Is there a relation between entrepreneurship and work innovation among nurse managers at Port Said governmental hospitals?

\section{SUBJECTS AND METHODS \\ TECHNICAL DESIGN:}

The technical design for this study was included a description of the research design, setting, subjects and tools of data collection.

\section{Research design:}

Descriptive correlational research design was used in the current study. 


\section{Settings:}

The study was carried out in seven Port Said governmental hospitals that affiliated to ministry of health namely: Port-Said general hospital, El-Zohour general hospital, El-Nasr hospital, Ophthalmology hospital, Fever hospital, Chest Disease hospitals and Obstetrics and Gynecology Specialist hospital.

\section{Subject:}

Convenient sample was used. The study subjects were included all nurse managers $(n=\mathbf{1 1 5})$ who were working in the aforementioned settings during the time of data collection who met the inclusion criteria with at least six months of experience in their current job and who agree to participate in the study.14 nurse managers were excluded to carry pilot study and only 101 nurse managers were included in the study.

\section{Data collection tools:}

Two tools were used in data collection

\section{Tool I: The characteristics of entrepreneurship questionnaire}

This tool includes two parts:

First part: Nurse Manager's characteristics sheet: It was developed by the researcher. It includes items related to personal data as hospital name, unit name, age, sex, marital status, educational level, years of experience in nursing, years of experience in current position and job title.

\section{Second part: The characteristics of entrepreneurship questionnaire}

It was developed by Ghannam (2017) and modified by the researcher. It is aimed to assess the characteristics of entrepreneurship. It consists of 42 items which categorized into seven dimensions namely: Initiative (six items), self-confidence (six items), independency and take responsibility (six items), risk taking (six items), need for achievement (six items), creativity (six items) and self-control (six items).

\section{Scoring system and interpretation}

Characteristics of entrepreneurship items were measured along five-point likert scales ranging from(5-1), for the responses strongly agree, agree, neutral, disagree and strongly disagree for each area, the score of the items were summed up and total divided by the number of the items, gives a mean score for the entrepreneurship .To estimate the cut of point, 
the median was calculated (178.0) and divided by the total score of entrepreneurship questionnaire (210) giving a result $(\mathbf{0 . 8 4 7})$; this score converted in to a percentage score (cut of point $\mathbf{8 5 \%}$ ) the subject was considered have entrepreneurship if the percentage score was $85 \%$ or more and haven't entrepreneurship if less than $85 \%$.

\section{Tool II: Work innovation questionnaire}

It was adopted from Saleh (2013) and modified by the researcher. It is aimed to measure work innovation among nurse managers. It consists of 51 items which categorized into four dimensions namely: the ability to innovate (eight items), problem solving abilities (11 items), decision-making ability (16 items), risk-taking, encouragement and moral support of innovation abilities (16 items).

\section{Scoring system and interpretation}

Work innovation items were measured along five-point likert scales ranging from (5-1), for the responses strongly agree, agree, neutral, disagree and strongly disagree for each area, the score of the items were summed up and total divided by the number of the items, gives a mean score for work innovation. To estimate the cut of point, the median was calculated (207.0) and divided by the total score of work innovation questionnaire (255) giving a result (0.811); this score converted in to a percentage score (cut of point $\mathbf{8 1 \%}$ ) the subject was considered have work innovation if the percentage score was $\mathbf{8 1 \%}$ or more and haven't work innovation if less than $81 \%$.

\section{OPERATIONAL DESIGN:}

\section{Operational design.}

The operational design covers the preparatory phase includes reliability, validity, pilot study and field work.

\section{Preparatory phase:}

Review of current national and international related literature, articles, periodicals, Egyptian knowledge bank and internet of the various aspects concerning the entrepreneurship and work innovation was done. The Characteristics of entrepreneurship and work innovation tool were revised with supervisors and modified, and then validity and reliability were tested. Getting the preliminary approval of the medical and nursing directors of the selected hospitals was also started at this stage. 


\section{Validity:}

The tools of the study were considered as a good content validity. The first tool the characteristics of entrepreneurship questionnaire were validated by Ghannam (2017) and the second tool work innovation questionnaire was validated by Saleh (2013) and revalidated in the current study that shows in the table (1).

\section{Validity statistics for entrepreneurship and work innovation dimensions}

\begin{tabular}{|l|c|c|}
\hline & $\mathbf{r}$ & $\mathbf{p}$ \\
\hline Entrepreneurship dimensions & 0.799 & $0.003^{*}$ \\
Initiative & 0.885 & $0.001^{*}$ \\
Self-confidence & 0.862 & $0.001^{*}$ \\
Independency and take responsibility & 0.686 & $0.020^{*}$ \\
Risk taking & 0.724 & $0.012^{*}$ \\
Need for achievement & 0.686 & $0.020^{*}$ \\
Creativity & 0.735 & $0.010^{*}$ \\
Self-control & & \\
\hline Work innovation dimensions & 0.724 & $0.012^{*}$ \\
The ability to innovate & 0.744 & $0.009^{*}$ \\
Problem solving & 0.855 & $0.001^{*}$ \\
Decision-making & 0.875 & $0.001^{*}$ \\
Risk-taking, encouragement and moral support & & \\
of innovation & & \\
\hline r: Pearson coefficient & & \\
\hline
\end{tabular}

\section{Pilot Study:}

A pilot study was carried out on 14nurse managers, 2 head nurse from the seven studied hospitals who represent $10 \%$ of the total sample from the studied hospitals of research work to assure the stability of the answers. the purpose of the pilot study was to test the and applicability, feasibility, objectivity and to estimate the needed time to fill the data collection sheets then necessary modification was done according to the result pilot study. They were excluded from the original sample. The pilot study was conducted for one week. 


\section{Reliability:}

Cronbach's alpha coefficient was calculated to assess the internal consistency of the tool, the characteristics of entrepreneurship questionnaire was (0.94) by Ghannam (2017) and work innovation questionnaire was (0.89) by Saleh (2013) and re-testing by using Cronbach's alpha coefficient in the current study the characteristics of entrepreneurship questionnaire was (0.93) and work innovation questionnaire was (0.93).

\section{Field work:}

- The data was collected from nurse managers by the researcher after obtaining an official agreement from the medical and nurse directors of the studied hospitals meeting with the nurse directors was conducted by the researcher on the individual basis to explain the objectives of the study and gain their cooperation.

- The questionnaire sheet was filled in by nurse managers while they on duty only in the morning shift, and after explain the purpose of the study

- Data were collected by the researcher and the team at three days per week in the morning shift from all seven hospitals.

- Data were collected from 3/8/2018 to $15 / 10 / 2018$.

\section{Administrative design.}

An official letter from the dean of the faculty of nursing and vice dean for post-graduate studies and researches was sent an official letter to aforementioned settings directors. After the explanation of the purpose of the study, a written permission was taken from them. On data collection, a verbal agreement was taken from every nurse manager participated in the study, after a clear explanation of the aim and objectives of the study.

\section{Ethical Considerations:}

- An informed consent was obtained from nurse managers and some of them take their permission by informed incent to participate in the study after explaining the purpose and the nature of the study.

- The studied nurse managers was informed that their participation is voluntary and they have the right of withdrawing from the study at any time and ensuring the confidentiality of the information collect and anonymity is guaranteed. 


\section{Statistical Design:}

\section{The Statistical Design includes the following:}

\section{Data coding}

The collected data was coded and present by using suitable tables. Data entry and statistical analysis were done using IBM SPSS software package version 20.0.

\section{RESULTS:}

It was founded that the highest percentage of the studied nurse managers age ranging between 30 years to 40 years. Besides the majority of them were married. Regarding to nursing qualification levels, it was observed that more than half (54.4\%) of nurse managers had Bachelor degree in nursing. Concerning to experience years in nursing filed, the highest percentages $(56.4 \%)$ of nurse managers were more than 15 years who mentioned that the experience years in present position, the highest percentages of nurse managers were under less than five years

Table (1): Shows characteristics of entrepreneurship for each dimension among nurse managers. As represented in the table, $47.5 \%$ of nurse managers reported that they have entrepreneurial characteristics. Whereas, $52.5 \%$ of them haven't entrepreneurial characteristics.

Table (2): Shows work innovation for each dimension among nurse managers. As represented in the table, $\mathbf{4 7 . 5 \%}$ of nurse managers reported that they have work innovation. Whereas, $60.4 \%$ of them have innovation regarding to problem solving. While, $52.5 \%$ of them haven't work innovation.

Table (3): shows the correlation between nurse managers' total scores characteristics of entrepreneurship and the total work innovation. It was evidenced that there was strongly statistically significant correlation between nurse managers' characteristics of entrepreneurship and the total scores work innovation $(\mathbf{p}<\mathbf{0 . 0 5})$ 
Table (1): Characteristics of entrepreneurship for each dimension among managers at Port Said governmental hospitals $(\mathrm{n}=101)$

\begin{tabular}{|l|c|c|c|c|}
\hline \multicolumn{1}{|c|}{$\begin{array}{c}\text { Characteristics of } \\
\text { entrepreneurship dimension }\end{array}$} & \multicolumn{2}{|c|}{$\begin{array}{r}\text { Have entrepreneurial } \\
\text { Characteristics }\end{array}$} & \multicolumn{2}{c|}{$\begin{array}{r}\text { Haven't entrepreneurial } \\
\text { Characteristics }\end{array}$} \\
\cline { 2 - 5 } & No. & \%5\% & No. & $\%$ \\
\hline Initiative & 57 & 56.4 & 44 & 43.6 \\
\hline Self-confidence & 49 & 48.5 & 52 & 51.5 \\
\hline Independency and take & 55 & 54.5 & 46 & 45.5 \\
responsibility & 52 & 51.5 & 49 & 48.5 \\
\hline Risk taking & 54 & 53.5 & 47 & 46.5 \\
\hline Need for achievement & 61 & 60.4 & 40 & 39.6 \\
\hline Creativity & $\mathbf{4 8}$ & $\mathbf{4 7 . 5}$ & $\mathbf{5 3}$ & $\mathbf{5 2 . 5}$ \\
\hline Self-control & Thetal & 53.5 & 47 & 46.5 \\
\hline
\end{tabular}

Table (2): work innovation for each dimension among nurse managers at Port Said governmental hospitals $(\mathrm{n}=101)$

\begin{tabular}{|l|c|c|c|c|}
\hline \multicolumn{1}{|c|}{ Dimension of Work Innovation } & \multicolumn{2}{|c|}{$\begin{array}{c}\text { Have work } \\
\text { innovation } \geq 81 \%\end{array}$} & \multicolumn{2}{c|}{$\begin{array}{c}\text { 81 wovation }< \\
\text { 81\% }\end{array}$} \\
\cline { 2 - 5 } & No. & $\%$ & No. & $\%$ \\
\hline Ability to innovate & 52 & 51.5 & 49 & 48.5 \\
\hline Problem solving & 61 & 60.4 & 40 & 39.6 \\
\hline Decision-making & 46 & 45.5 & 55 & 54.5 \\
\hline Risk-taking, encouragement and \\
moral support of innovation
\end{tabular}


Table (3): Correlation between nurse managers' total characteristics of entrepreneurship and their total work innovation $(n=101)$

\begin{tabular}{|c|c|c|}
\hline \multirow{2}{*}{ Variables } & \multicolumn{2}{|c|}{ work innovation } \\
\cline { 2 - 3 } & r & p \\
\hline $\begin{array}{l}\text { Characteristics of } \\
\text { Entrepreneurship }\end{array}$ & $\mathbf{0 . 8 5 3}^{*}$ & $<0.001^{*}$ \\
\hline
\end{tabular}

r: Pearson coefficient

*: Statistically significant at $\mathrm{p} \leq 0.05$

\section{DISCUSSION:}

The present study aims to examine the relation between entrepreneurship and work innovation among nurse managers at Port Said governmental hospitals through assess the characteristics of entrepreneurship among nurse managers, assess work innovation among nurse managers and find out the relation between entrepreneurship and work innovation among nurse managers at Port Said governmental hospitals.

Regarding the characteristics of entrepreneurship among nurse managers, the finding of the present study revealed that about half of nurse manager haven't characteristics of entrepreneurship. These findings probably due to nurse managers have low self-confidence and low risk taking.

This finding was in accordance with Nasser \& Al-Omari (2011) who measuring the characteristics of entrepreneurship among master students in administration and its impact on entrepreneurship in Damascus University and their results were master students have moderate entrepreneurial characteristics. But, the current study in contrast with Dehghanzadeh, Kholasehzadeh, Birjandi, Antikchi, Sobhan \& Neamatzadeh (2013) who assess Entrepreneurship Psychological Characteristics of Nurses in the Shahid Sadoughi Hospital,Yazd, Iran who found that the majority of the nurses strong entrepreneurship characteristics.

Regarding the work innovation among nurse managers, the finding of the present study revealed that the majority of nurse manager haven't work innovation. These findings probably 
due to nurse managers have problem in decision-making that help them to create and innovate or not adopt every new method or ideas.

The same with current study Wang\& Yang (2019) in their study: The mediating role of inclusive leadership: Work engagement and innovative behavior among Chinese head nurses who stated that the level of innovative behavior among head nurses was in the middle level. But, Saleh (2013) in his study Analyzing the relationship between administrative empowerment and innovative administrative behavior, a field study for managers of the administrative system at Taif University, disagreement with the current study who stated that managers of the administrative system have high level of work innovation.

As regard to correlation between nurse managers' characteristics of entrepreneurship and their work innovation. It was evidenced that there was strongly statistically significant correlation between nurse managers' total scores characteristics of entrepreneurship and the total scores work innovation. The current study agrees with Ndubisi (2012) who study the Relationship between entrepreneurship, innovation and performance: Comparing small and medium-size enterprises. The results indicate a significant direct relationship between entrepreneurship and innovation. In the same context Bagheri (2017) who study the impact of entrepreneurial leadership on innovation work behavior and opportunity recognition in hightechnology SMEs. found that a significant impact of entrepreneurial leadership on innovation work behavior. Moreover, Arqawi, Herzallah\& Mufid (2020) in their study: Administrative innovation and entrepreneurship Strategy (Relationship and Impact Case study In the Palestinian Islamic Development Company) agree with the current study who found a correlation and impact between innovation and the entrepreneurial for workers in the Islamic Palestinian Development Company.

\section{CONCLUSION:}

The study revealed that about half of nurse managers haven't entrepreneurial characteristics and about half of nurse managers haven't work innovation. There was statistically significant positive correlation between nurse managers' total scores characteristics of entrepreneurship and the total scores work innovation. 


\section{RECOMMENDATIONS:}

1. Supporting nurse manager's self-confidence and risk taking by providing a working environment contribute the explosion of energies and the generation of ideas that lead to raise organization growth and improvement.

2. Encourage the creation of innovative ideas, designing and implementing specialized training courses in the fields of problem solving, creative thinking and decision-making to be able for dealing with situations and crises, was a significant impact on development the spirit of creativity and innovation for nurse managers.

3. Attend conferences, workshops and training program about entrepreneurship characteristics and work innovation to create an entrepreneurial character who contributes to develop their work and developing their behavioral skills to suit the work environment.

\section{REFERENCES:}

American Nurses Association, ANA. (2017). American Nurse Association Research: innovation. Retrieved from https://www.nursingworld.org/practice-policy/innovation/.Access May 30, 2019.

Andrade, A., Dal Ben, L. W., \& Sanna, M. C. (2015). Entrepreneurship in Nursing: overview of companies in the State of São Paulo. Brazilian nursing journal, 68 (1), 35-44. Retrieved from https://doi.org/10.1590/0034-7167.2015680106p.

Arqawi, Samer \& Herzallah, Fadi \& Mufid, Suha. (2020). “Administrative Innovation and Entrepreneurship Strategy: Relationship and Impact Case study In the Palestinian Islamic Development Company. 8. 47-67.

Bagheri, A. \& Akbari, M. (2018), "The impact of entrepreneurial leadership on nurses' innovation behavior”, Journal of Nursing Scholarship, 50 (1), 28-35.

Bagheri, A. (2017). The impact of entrepreneurial leadership on innovation work behavior and opportunity recognition in high-technology SMEs. The Journal of High Technology Management Research, 28, 159-166.

Carla S. Marques \& \& João J. M. Ferreira \& Fernando A. F. Ferreira, (2019). "Effects of traits, self-motivation and managerial skills on nursing intrapreneurship," International Entrepreneurship and Management Journal, Springer, vol. 15(3), pages 733-748, September. 
Chen, Y. (2014). CEOs' Transformational Leadership and Product Innovation Performance: The Roles of Corporate Entrepreneurship and Technology Orientation. Journal of Product Innovation Management. 31. 10.1111/jpim.12188.

De Jong, J. P., \& Den Hartog, D. N. (2010). Innovative work behavior: Measurement and validation. EIM Business and Policy Research, 8(1), 1-27.

Dehghanzadeh, M. R., Kholasehzadeh, G., Birjandi, M., Antikchi, E., Sobhan, M. R., \& Neamatzadeh, H. (2016). Entrepreneurship Psychological Characteristics of Nurses. Acta $\begin{array}{llll}\text { medica } & \text { Iranica, } & \text { 54(9), } & \text { Available }\end{array}$ from: https://www.ncbi.nlm.nih.gov/pubmed/27832692 .

Hisrich, R. D., \& Kearney, C. (2014). Managing Innovation and Entrepreneurship. A Global Perspective.SAGE Publications. available on SAGE Knowledge, the ultimate social sciences online library.

İrmiş, A. \& Özdemir, L. (2011), Entrepreneurship and Innovation Relationship, Journal of Management Sciences, 9 (1), 139-161.

Jahani, S., Abedi, H., Khoshknab, M., Elahi, N., (2018).The experience of Iranian entrepreneurial nurses on the identification of entrepreneurial opportunities: A qualitative study. J Family Med Prim Care; 7(1):230-236. doi: 10.4103/jfmpc.jfmpc_233_17.

Japanese Nursing Association. (2016). Nursing in Japan. Available from: http://www.nurse.or.jp/jna/english/pdf/nursing-in-japan2016.pdf [last accessed 20 /4/ 2018].

Kartal, H. K. (2018). Nursing Innovation Examples. Journal of Health and Nursing Management, 1(5), 57-61.

Kaur, K. D., \& Gupta, V. (2016). The Impact of Personal Characteristics on Innovative Work Behaviors: An Exploration into Innovation and Its Determinants amongst Teachers. The International Journal of Indian Psychology, 3(3).

Kheng, Y.K \& Mahmood, R. (2013). The Relationship between Pro-Innovation Organizational Climate, Leader-Member Exchange and Innovative Work Behavior: A Study among the Knowledge Workers of the Knowledge Intensive Business Services in Malaysia, journal of Business Management Dynamics, 2(8), 15-30 
Koe, W., Sa'ari, J., Majid, I., \& Ismail, K. (2012). Determinants of Entrepreneurial Intention Among Millennial Generation. Procedia - Social and Behavioral Sciences, 40. Available at https://doi: 10.1016/j.sbspro.2012.03.181

Marques, C.S., \& Ferreira, J.J.M. (2019). Effects of traits, self-motivation and managerial skills on nursing intrapreneurship. International Entrepreneurship and Management Journal, Springer, 15(3), 733-748.

Merriam-Webster Collegiate Dictionary. Entrepreneur. 2016. Available at https://www.merriam-webster.com/dictionary/entrepreneur access at 8 PM, 16/7/2020

Messmann, G. (2017). Joint effects of job demands and job resources on vocational teachers' innovative work behavior. Personnel Review, 46(8), 1948-1961.

Moloi, K.C., \& Nkhahle-Rapita, M.A. (2014). The Impact of Fashion Entrepreneurs' Traits on the Success of Fashion Businesses in the Gauteng Province in South Africa. Mediterranean Journal of Social Sciences, 5(4):78-86.

Nasser,M.G., \&Al- Omary.G. (2011) .Measurement of entrepreneurial characteristics among graduate students in business administration and its impact on entrepreneurial work. Damascus University. Journal for Economic and Legal Sciences, 27, (4).

Nawrat, D. (2013). Shaping innovative competences in the light of the research on managers' biographies, in: Entrepreneurial manager of an entrepreneurial organization, Journal of Entrepreneurship and Management ,14, (4).

Ndubisi, N. (2012), "Relationship between entrepreneurship, innovation and performance: Comparing small and medium-size enterprises", Journal of Research in Marketing and Entrepreneurship, 14 (2), 214-236. Available from https://doi.org/10.1108/14715201211271429

O’Connor, A. (2013), “A conceptual framework for entrepreneurship education policy: meeting government and economic purpose", Journal of Business Venturing, 28, 546563.

Ogundele O. J. K \& Abiola J. O. (2012). Entrepreneurship and National Development: A Proposal for Evangelistic Agenda. European Scientific Journal (March Edition, 8(6)

Peverelli, P. J. \& Song, J. (2012). Chinese Entrepreneurship, DOI Proposal AND implementation of the ETOILe model. Presented at the Innovation Research Network 
Summer Forum, Nancy. Retrieved from Doi: 10.1007/978-3-642-28206-5_2, Springer-Verlag Berlin Heidelberg.

Saleh, M. (2013). Analyzing the relationship between administrative empowerment and innovative administrative behavior, a field study for managers of the administrative system at Taif University.

Singer, S., Amoros, J. \& Arreola, D. (2015), Global Entrepreneurship Monitor 2014 Global Report, Global Entrepreneurship Research Association, London.

Smith, L., Rees, P., \& Murray, N. (2016). Turning entrepreneurs into intrapreneurs: Thomas Cook, a case-study. Tourism Management, 56, 191-204. Retrived from https://doi.org/10.1016/j.tourman.2019.11.005

Turkish Language Society (TLS). (2019). Dictionary. Retrived: http://www.tdk.gov.tr (Date of access: 07.06.2019)

Wang, Y.X., \& Yang,Y.G., (2019). The mediating role of inclusive leadership: Work engagement and innovative behaviour among Chinese head nurses. Journal of nursing management, 27(4), 688-696. DOI: 10.1111/jonm.12754.

Weng, R. H., Huang, C. Y., \& Lin, T. E. (2013). Exploring the cross-level impact of market orientation on nursing innovation in hospitals. journal of Health Care Management Review, 38(2), 125-136.

Wilson, A., Whitaker, N., \& Whitford, D. (2012). Rising to the challenge of health care reform with entrepreneurial and intrapreneurial nursing initiatives. Online journal of issues in nursing, 17(2), 5.

Zhou, J. (2018). Serial multiple mediation of organizational commitment and job burnout in the relationship between psychological capital and anxiety in Chinese female nurses: A cross-sectional questionnaire survey. International Journal of Nursing Studies, 83, 75-82. 
الريادة والابتكار في العمل لادي مدراء التمريض في المستثفيات الحكومية ببورسعيد

سميعة محسن وردان 1 ، أ.د/ سناء عبد العظيم إبراهيم2 ، د/ غادة مسعد محمد الغبور 3

\section{الخلاصة}

الريادة والابتكار أساسًا مهمًا للميزة التنافسية في بيئة العمل وتعزيز القدرات لنمو العمل وثروة الأمم ، هدفت الدراسة الحالية إلى دراسة العلاقة بين الريادة والابتكار في العمل بين مديري التمريض في مستشفيات بورسعيد الحكومية، تم استخدام تصميم بحث وصفي ارتباطي للار اسة الحالية و أجريت هذه الدر اسة في سبعة مستشفيات حكومية ببورسعيد وهي: مستشفى بورسعيد العام (مستشفى السلام) ، ومستشفى الزهور العام ، ومستشفى النصر ، ومستشفى العيون ، ومستشفى الحمات ، ومستشفيات أمر اض الصدر و المستشفى التخصصي لأمر اض النساء و الولادة، تضمنت هذه الدراسة (101)

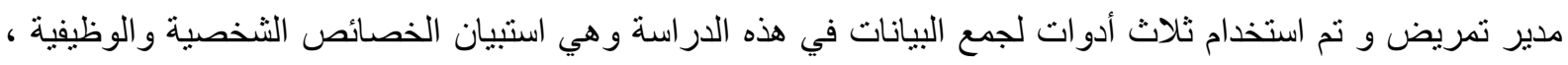
و واستبيان خصائص الريادة واستبيان الأبتكارفي العمل ، كثنت الدراسة أن غالبية مديري التمريض ليس لديهم خصائص ريادية و غالبية مديري التمريض لم يعملوا على الابتكار. الخلاصة: كان هناك ارتباط إيجابي ذات دلالة إحصائية بين خصائص الدرجات الإجمالية لمديري التمريض في ريادة الأعمال وإجمالي الدرجات في الابتكار في العمل. التوصيات: تحسين الثقة بالنفس من خلال المزيد من المشاركة وتشجيع قدرتهم على تحقيقها. حضور المؤتمرات وورش العمل وبرنامج التنريب حول خصائص الريادة والابتكار في العمل لخلق شخصية ريادية. الكلمات المرشدة : الريادة ،الابتكار ، مدير التمريض الريادي. 